Снежана Елесиевич

Белградский университет

Филологический факультет

Кафедра славистики

snezana.jelesijevic@fil.bg.ac.rs
УДК 821.161.1.09"14"

https://doi.org/10.18485/slavistika.2021.25.1.9

Оригинални научни рад

примљено 14.05.2021.

прихваћено за штампу 17.06.2021.

\title{
БОЛГАРСКИЙ СПИСОК «ПОУЧЕНИЯ О ПОЛЬЗЕ ДУШЕВНОЙ» МИТРОПОЛИТА КИЕВСКОГО ИЛАРИОНА
}

В статье вкратце излагается история исследования «Поучения о пользе душевной» и вопроса о его авторе. Публикуется болгарский список «Поучения», в надписании которого автор обозначен как «Святой Иларион, митрополит Киевского града». Список находится в рукописи собрания Печской патриархии, № 93, датированной первым десятилетием XV века. К изданию болгарского списка поучения разночтения указаны по изданию, подготовленному прот. Александром Горским, и по древнерусскому списку конца XIV - начала XV века РГБ, ТСЛ, № 13. Автор также приводит данные о сербских списках поучения.

Ключевые слова: митрополит Иларион, «Поучение о пользе душевной», Печская патриархия.

This article outlines in brief the research history of The Sermon on Spiritual Benefit and the question of its writer. The Bulgarian copy of The Sermon is published within it. According to the title of this copy, the writer of the sermon is "Saint Hilarion, Metropolitan of the city of Kiev's". The copy has been preserved in the manuscript in a collection of the Patriarchate of Peć № 93, dated to the first decade of the $15^{\text {th }}$ century. The published copy has been followed by variant readings from archpriest Alexander Gorsky's edition and from the Old Russian copy in Manuscript 13 of the Holy Trinity-St. Sergius Lavra Collection (the Russian State Library), dated to the late $14^{\text {th }}-$ early $15^{\text {th }}$ centuries. The author also gives information about Serbian copies of the sermon.

Keywords: Metropolitan Hilarion, Sermon on Spiritual Benefit, the Patriarchate of Peć.

«Поучение о пользе душевной» было введено в научный оборот протоиереем Александром Васильевичем Горским в 1844 году. Ему были известны три древнерусских списка - в Сборнике полемических, канонических и исторических статей собрания Московской духовной академии (РГБ), № 175, XVI и XVII вв. ${ }^{1}$ (лл. 156 об.-158), в одной из рукописей Волоколамской библиотеки и в «харатейном» сборнике библиотеки М. П. Погодина, в 16 долю, конца XIV или начала XV века (Горскій 1844: 218-219, 293). ${ }^{2}$ Волоколамская рукопись не установлена (Турилов и др. 2009: 125). Пергаменные сборники собрания М. П. Погодина - №№ 66, 67, 716 (Гранстрем 1953: 53, 59, 72), согласно их описанию, этого поучения не содержат и по формату не соответствуют упомянутому Погодинскому сборнику (Творогов, Загребин 1988: 57-58, 61-62).

В списке РГБ, МДА, № 175 надписание поучения гласит: поүченїе (!)

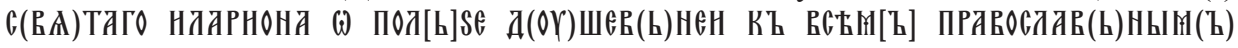

${ }^{*}$ Расширенная версия доклада, прочитанного на 59 собрании славистов Сербии (Белград, 28-29 января 2021 г.).

${ }^{1}$ Описание см.: Леонид 1887: 182-200, № 10 (175).

${ }^{2}$ В той же статье прот. А. В. Горским были опубликованы и Иларионовы «Слово о законе и благодати» и «Исповедание веры» (Горскій 1844: 223-292). 
ХРНСТ̈̈АнонҺ (156 об.). Оно, очевидно, и дало ему имя в научной литературе начиная со статьи прот. А. В. Горского (Горскій 1844: 219; Турилов и др. 2009: 125; ${ }^{3}$ Јелесијевић 2012а: 182; Јелесијевић 2012б, I: 206). ${ }^{4}$ В Волоколамском и Погодинском списках заглавия иные: «слово святаго Иларіона Митрополиты Кіевскаго» (Горскій 1844: 219); «Святаго Иларіона, Митрополита Кіевскаго, слово» (Горскій 1844: 293). ${ }^{5}$

В основу издания поучения (Горскій 1844: 293-296) прот. А. В. Горским, судя по всему, был положен Волоколамский список. Им был использован и Погодинский, по которому подводились разночтения к основному списку (Горскій 1844: 293, 294, 296). Одно чтение Погодинского списка (два слова), по всей видимости, было включено в основной список, с приведением к нему разночтения по основному или Волоколамскому (Горскій 1844: 295). Академический список нередко отличается от издания. В нем представлена, на наш взгляд, более поздняя редакция поучения, заслуживающая отдельного внимания. По нему были указаны только два разночтения. Три были включены в основной список, ${ }^{6}$ с приведением к ним разночтений по Волоколамскому и Погодинскому (Горскій 1844: 294-295, 296). Среди этих чтений - отсутствие двух обращений к инокам («о иноци»), имеющихся в Волоколамском и Погодинском списках. Издатель исключил их из основного списка, в соответствии с Академическим, потому что, согласно надписанию в последнем, поучение было обращено ко всем православным христианам. К этому объяснению он добавляет, что по содержанию обличений поучение более подходит мирянам, чем монахам (Горскій 1844: 294, 296). В другом месте он и прямо говорит, что это поучение к мирянам, а не наставление иноческое (Горскій 1844: 219). Издание сопровождается переводом на русский язык (Горскій 1844: 297-299).

Пробиваясь сквозь толщу веков, живо и мощно звучат слова пастыря, актуальные пока стоит мир. Он обращается к братьям и сестрам и, заботясь об их спасении, доходчиво и настоятельно напоминает о необходимости христианского подвига для достижения главной цели - жизни вечной.

Прот. А. В. Горский не сомневался в принадлежности поучения перу митрополита Илариона: помимо указания на его авторство, в этом его убеждал и «слог поученія, по списку Волоколамскому», показывающий «глубокую древность сочиненія» (Горскій 1844: 219-220). Он полагал, что такой атрибуции не препятствует и содержание поучения (Горскій 1844: 219-220). Его мнение приняли архиепископ Филарет (Гумилевскій 1884: 10) и В. М. Ундольский, ${ }^{7}$ в отличие

${ }^{3} \mathrm{~B}$ этой статье название поучения звучит несколько иначе: «Поучение св. Илариона о пользе души».

${ }^{4}$ Иногда, именуя поучение, исследователи, видимо, исходят из его надписания в конкретном списке или воспроизводят его в переводе на современный язык: «Слово митрополита Илариона» (Турилов 2011: 16; Турилов 2014: 171-172), «Слово о подвизавању ка Богу укратко» (Јелесијевић 2012а: 182).

${ }^{5}$ О митрополите Иларионе см.: Турилов и др. 2009: 122-126.

${ }^{6}$ Одно из них передано неточно: «и инъми житія сего дълы» (Горскій 1844: 294) - І ннымн жнтїА сєго дъды (РГБ, МДА, № 175, л. 157).

${ }^{7}$ Сообщая о мнении В. М. Ундольского, Н. К. Никольский отсылает к «его Указателю 
от митр. Макария, обосновавшего свою точку зрения несколькими доводами: в большинстве рукописей поучение приписывается святому Илариону, преподобному Илариону или Илариону Великому, именами которых надписаны многие поучения в русских рукописях; оно встречается наряду с другими поучениями Илариона Великого; в списках Пролога и в печатном Прологе оно помещено под 21 октября, днем памяти Илариона Великого и Илариона Мегленского, за сказаниями о том и другом; по слогу, составу и скудости содержания поучение нисколько не похоже на два подлинных сочинения митрополита Илариона (Булгаков 1995: 179-180, 473).

Н. К. Никольский указал 60 русских списков поучения, восходящих к XIIIXVIII вв., не включая в их перечень все проложные списки (Никольскій 1906: 106-110, 513). Согласно этим данным, только в одном из списков, находящемся в пергаменном Сборнике РГБ, ТСЛ, № $13,{ }^{8}$ конца XIV - начала XV века ${ }^{9}$ (лл. 210-212 об.), поучение приписывается митрополиту Киевскому Илариону: СПОвО С(ВА)Т(А)ГО ЛАРНОНА (!) ННТРОПОЛНТА КНЮЕВьСКОГО (л. 210). ${ }^{10}$ Помимо Поучения в виде, представленном списками РГБ, ТСЛ, № 13, Волоколамским и Погодинским, в русской рукописной традиции имеется и его сокращенная редакция (Буланин (ред.) 2014: 161) или сокращенная проложная версия (Турилов 2011: 17; Турилов 2014: 172, 187). Ее список, с именем святого Илариона в заглавии, в учительной части Пролога РНБ, Соф., № 1324, середины - второй половины XIII века, свидетельствует о домонгольской датировке поучения (Турилов и др. 2009: 125). ${ }^{11}$

По указанию на митрополита Киевского Илариона как автора к спискам РГБ, ТСЛ, № 13, Волоколамскому и Погодинскому примыкают два сербских списка пространной редакции поучения - в Сборнике БАН, Тек. пост., № 13, третьей четверти XIV века ${ }^{12}$ (лл. 36 об.-38 об.) и Сборнике слов святых отцов НБС, № 26, также третьей четверти XIV века (Штављанин-Ђорђевић и др. 1986: 45-52) (лл. 106 об.-108). В них Иларион, митрополит Киевский, назван не прямо, а с отсыл-

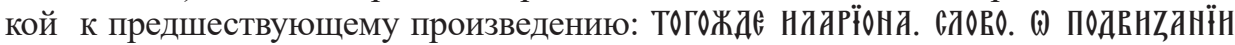
Кь Б(ОГ)ㅇ вь КРАТ’ЦҺ (БАН, Тек. пост., № 13, л. 36 об.) (Јелесијевић 2012а: 182;

слав. русск. сочиненій и переводовъ въ рукописи Ундол. № 1491, подъ именемъ: Иларіонъ митроп. Кіевскій» (Никольскій 1906: 105). В шифре, по-видимому, допущена опечатка должно быть 1401. Ныне «Указатель», сохранившийся в автографе В. М. Ундольского, находится в РГБ, ф. 704, к. 12, № 1 (см.: Опись фонда № 704: 2, 20). Предполагаем, что Н. К. Никольский имел в виду сведения в разделе на букву П, на л. 449. Те же сведения есть и в другом указателе В. М. Ундольского - «Агиологионе» РГБ, ф. 704, к. 13, № 1, л. 297 об. (старый шифр 1400). См.: Опись фонда № 704: 2, 21.

${ }^{8}$ Описание см.: [Иларий, иером. и др.] 1878: 22-23.

${ }^{9}$ Датировка приводится по: Турилов 2011: 17; Турилов 2014: 187.

${ }^{10}$ Исследователь задается вопросом, не с этой ли рукописи («въ видъ fac-simile») сделан список поучения в рукописи Ундольского № 1411, на лл. 1-3 об. (Никольскій 1906: 107). Его догадка оказалась верной. Сегодня этот список, автограф В. М. Ундольского, находится в РГБ, ф. 704, к. 23, № 28 (см.: Опись фонда № 704: 38).

${ }^{11}$ Литературу о поучении, включая издания, см.: Буланин (ред.) 2014: 161 .

${ }^{12}$ Отсылку к литературе о рукописи и ее писце см.: Елесиевич 2014: 223. 
Јелесијевић 2012б, I: 209; Буланин 2014: 574). ${ }^{13}$ Такое название поучения нам известно только по этим спискам. Им предшествует слово. НлаРїона ННТРОПОЛНТА

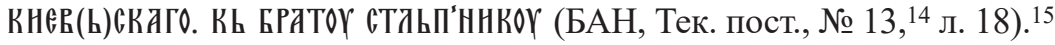

Определение «Киевский» в титуле митрополитов всея Руси впервые встречается в 1347 году, на греческом языке, в акте Константинопольского патриархата, и относится к митрополиту Феогносту (Vetochnikov 2014: 275, 298, $299,300,301) .{ }^{16}$ Оно имеется и в заглавиях посланий митрополита Никифора I (1104-1121), ${ }^{17}$ но в поздних списках (кон. XV - нач. XVI в., XVI в., XVII в.) (Громов и др. (ред.) 2006: 29, 89, 95, 96, 124, 129, 153, 199, 212, 241, 244, 251, 262, 276, 303, 306; Vetochnikov 2014: 291-292, 299). Оказывается, что древнейшие упоминания «митрополита Киевского» как автора, в надписании произведений, до нас дошли в четырех сербских списках «Слова к брату столпнику» и, опосредованно, в двух сербских списках «Поучения о пользе душевной».

Митрополиту Илариону это поучение приписывается и в болгарском списке Аскетического сборника собрания Печской патриархии, № 93, первого десятилетия XV века. ${ }^{18} \mathrm{~A}$. А. Турилов точнее определяет извод сборника как западноболгарский (Турилов 2011: 16; Турилов 2014: 171, 187). Кодекс открывается Римским патериком (лл. 1-86), начало которого утрачено (Иванова 2008: 104; Турилов 2011: 16; Турилов 2014: 171, 187). Содержит и Скитский устав (Мошин

${ }^{13}$ Издание списка БАН, Тек. пост., № 13 с разночтениями по НБС, № 26 и РГБ, ТСЛ, № 13 см.: Јелесијевић 2012б, II: 157-159. Есть и сербский список сокращенной редакции (МС PP I 22, ок. 1696-1705 гг.) и перевод-обработка пространной на сербском языке, выполенный Гаврилом Стефановичем Венцловичем (САНУ 271, 1732 г.), на который, ссылаясь на Каталог рукописей «српске кральевске академије», обратил внимание М. П. Петровский (Петровскій 1909: 130). О них см.: Јелесијевић 2012б, I: 130, 209, 210-21; Јелесијевић 2012а: 182. Издания см.: Јелесијевић 2012б, II: 160-169.

${ }^{14}$ Издание см.: Петровскій 1865: 13-35; Јелесијевић 2012б, II: 66-99.

15 «Слово к брату столпнику» только в сербских списках приписывается митрополиту Киевскому Илариону. Помимо упомянутых, есть еще два сербских списка с таким же заглавием - Хил., № 455 (ок. 1360-1370 гг.) (только начальная часть) и Сав., № 22 (ок. 1418 г.) (См.: Турилов 2009: 124; Турилов 2014: 146, 159; Елесиевич 2014: 223-230; Буланин 2014: $574,575,578,579-580,582,583-584,586-587,590)$. По ним, НБС, № 26 и другим спискам подведены разночтения в издании списка Тек. пост. 13: Јелесијевић 2012б, II: 66-99 (см. прим. 14). Издание Савинского списка см.: Јелесијевић 2012б, II: 100-117. В рукописи Хил., № 455 обнаружены две компиляции, состоящие из частей «Слова» со следами редакторской работы. О них и их издание см.: Елесиевич 2014: 224, 226-229, 230-233. О вопросе об авторстве «Слова» см.: Турилов и др. 2009: 124-125; Јелесијевић 2012а: 177-180; Буланин 2014: $575-577,579,583-587)$.

${ }^{16}$ Пользуемся возможностью поблагодарить российскую исследовательницу Елену Владимировну Белякову за консультацию и ряд статей по этому вопросу.

${ }^{17}$ О митр. Никифоре I см.: Веретенников и др. 2018: 621-627.

${ }^{18}$ Описания см.: Мошин 1968-1971: 100-102, № 99; Иванова 2008: 104, № 88. В кратком описании Д. Вуксана поучение не отмечено (Вуксан 1936: 181, № 103). Название рукописи приводится по: Иванова 2008: 104, № 88 («Сборник монашески»). Датировка по: Гроздановић-Пајић и др. 1991: 52, № 93. 
1968-1971: 101; Иванова 2008: 104) (лл. 188а-198 об.). ${ }^{19}$ А. А. Турилов отмечает, что среди чудес в Житии и чудесах Николая Чудотворца в конце кодекса (лл. 209-228) есть и те, которые относят к древнерусским домонгольским переводам (Турилов 2011: 16-17; Турилов 2014: 171, 187).

«Поучение о пользе душевной» в сборнике Печской патриархии озаглавле-

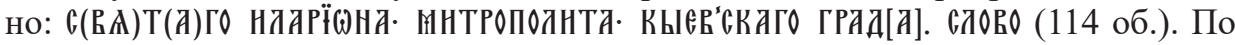
мнению А. А. Турилова, вопрос об авторстве поучения является предметом дисскусии, «но существование достаточно раннего (в рамках сохранившейся совокупной рукописной традиции) южнославянского списка указывает, как минимум, на домонгольскую древность подобного надписания» (Турилов 2011: 17; Турилов 2014: 172). Невольно вспоминается запись самого митрополита

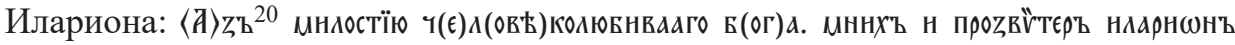

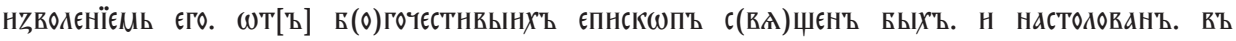

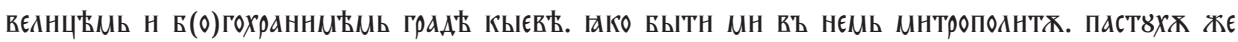
н оүчнтєлю. <..> (Молдован 1984: 7). В древнерусских источниках находим два

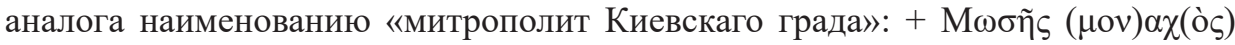
$\mu \eta(\tau) \rho о \pi о \lambda[i] \tau \eta \varsigma ~ \pi o ́ \lambda[\varepsilon] \omega \varsigma$ В $\lambda \alpha \delta \eta[\mu(i) \rho($ ov)] (печать, XII в.) (Vetochnikov 2012: 291, 300); ${ }^{21}$ (бт[ь] мнтрополнта поставлєнъ быс(ть) єп(н)с(ко)п(о)мь градү Түровү (проложное Житие свт. Кирилла, епископа Туровского ${ }^{22}$ ) (Лосева 2009: 351).

Поучение в Печской рукописи находится, по всей видимости, между патериковыми повестями. Поэтому получается, что следующая за ним повесть принадлежит митрополиту Илариону (ТъжАє от(ь)ць г(даго)А(А)шє, л. 115).

Стоит обратить внимание на гласный $у$ в начале слова оүпєрниь (л. 115). В сербском языке вь в начале слова после падения редуцированных перешло в $y$ (Младеновић 1971: 421). Такой языковой процесс отмечен в некоторых западноболгарских говорах, но между согласными, после падения следующего за в редуцированного переднего ряда. В восточноболгарских памятниках XVII века встречаются примеры: оүрьмє, оүратъ (Мирчев 1963: 132, 141). В берестяных грамотах после падения редуцированных вместо предконсонантного в иногда пишется or $(8$, r) (Зализняк 2004: 62, 64, 81). Некоторые отраженные в списке языковые черты, встречающиеся в болгарских рукописях (Мирчев 1963: 99, 100-101, 102, 103, 116-118), характерны для рукописей сербского извода (е < е̨; смешение н и ы, оттого что звук $ы$ исчез, совпав по произношению с $u$ ) (Младеновић 1971: 420).

Печский список «Поучения о пользе душевной» и его снимок публикуются в приложении (Прил. 1-2). ${ }^{23}$ При этом сохраняются орфография и пунктуа-

${ }^{19}$ Издание Скитского устава см.: Белякова 2003: 63-95. О его южнославянских и русских списках см.: Белякова и др. 2020: 54-57.

${ }^{20}$ В рукописи: зъ.

21 Это лицо в других источниках не упоминается. Возможно, это был Владимирский епископ, возведенный в митрополиты императором, а не патриархом (Vetochnikov 2014: 291).

${ }^{22}$ Время возникновения жития исследователями определяется по-разному: между рубежом XII-XIII вв. и концом XIII - началом XIV вв., во второй половине XIII в., в конце XIV начале XV вв., после монголо-татарского нашествия (Јелесијевић, в печати).

23 За снимок благодарим заведующего Музеем Сербской Православной Церкви диакона 
ция оригинала. Выносные буквы вносятся в строку. Буквы, опущенные в сокращениях под титлом, восстанавливаются и заключаются в круглые скобки, без титла - в квадратные. Надстрочные знаки не воспроизводятся, за исключением`. При раскрытии сокращений следуем норме «Лексикона» Ф. Миклошича. Буквы, опущенные в окончаниях склоняемых и спрягаемых слов, а также в суффиксах причастий, восстанавливаются в соответствии со старославянским языком. Такой принцип передачи текста соблюдался нами во всей статье, с той разницей, что, цитируя текст сербского извода, мы следовали норме словаря древнесербского языка Дж. Даничича и, в соответствии с сербским изводом, писали только ь. Приводя же древнерусский текст, мы руководствовались нормой словаря древнерусского языка И. И. Срезневского.

К Печскому списку (Печ.) подведены разночтения по Волоколамскому (В), который положен в основу издания прот. А. В. Горского, и РГБ, ТСЛ, № 175 (Т). Судя по изданию прот. А. В. Горского, Волоколамский и Погодинский (П) списки почти не отличаются друг от друга. Поэтому под разночтениями В можно подразумевать и разночтения П, за исключением чтений П, надежных или предположительных (?), отличающихся от В и совпадающих с Печ. (П = Печ.) (см. разночт. 57-59, 65). Разночтения в Т и В при их совпадении приводятся по Т.

В разночтения не включены языковые различия между изводами. Не принимается во внимание и разница, заключающаяся в отсутствии еров в Т и В и в соотношении л (Печ.) / а (Т, В); х (Печ.) / ъ (Т, В); $九$ Б (Печ.) / 九ґ (Т), ля (В); на (Печ.) / нг (Т), ня (В). Не придается значение написанию ь вместо $\epsilon^{24}$ в Т, В: можєтє (Печ., л. 115) / можєть (Т, В). Во избежание неясности и неверного представления о списках Т и В из них приводим разночтения к г(Ааго)лАџниь (14), ЖАнХть (20), впєрнць (58), плачАџе (61).

В Печском списке наблюдаются пропуски (см. разночт. 45, 50). Имеются два обращения к иноком, как в РГБ, ТСЛ, № 13, В и П.

Не раз напрашивалась мысль, что под Волоколамским прот. А. В. Горский имел в виду список РГБ, ТСЛ, № 13 (см., в частности, разночт. 57-58). Тогда расхождения между Т и В можно, предположительно, объяснить включением в основной список, помимо 57 (= МДА, № 175, л. 158)-58, и других чтений П. В таком случае в следующих разночтениях чтениями В на самом деле могут быть представлены чтения П: 16, 25 (МДА, № 175: вєдущємх, л. 157), 35, 39, 45, 47 (= МДА, № 175, л. 157 об.), 54, 56, 70, 76. Тогда в разночт. 17 не должно быть В. Имя проповедника издатель мог включить в заглавие издания из П (см. 1), а $\overrightarrow{\mathrm{H}}$ (см. 49) - из МДА, № 175 (л. 157 об.). Если Т и В не являются одним и тем же списком, можно предположить восхождение В к Т.

Результаты этого сопоставления будут учтены при издании сербских списков поучения. Из произведений, для которых есть основания приписать их митрополиту Илариону, на данный момент в болгарской письменности известно только «Поучение о пользе душевной» по Печскому списку. Существует болгарский список компиляции, состоящей из частей «Слова к брату столпнику», в

Владимира Радовановича и сотрудников Музея.

${ }^{24}$ Об этом см.: Живов 2017: 707-710. 
Патерике сводном НБКМ, № 1036, 60-70-х гг. XIV в. (лл. 243-245), ${ }^{25}$ такой же как в рукописи Хил., № $455^{26}$ (Елесиевич 2014: 224, 228-229, 231-233). Первое из двух Иларионовых произведений, опубликованных Б. Ангеловым по рукописи болгарского извода Румынской академии наук, № 294, XVI века 27 (Ангелов 1958: 227-23528), является на самом деле компиляцией, содержащей два переделанных отрывка «Слова к брату столпнику» (Буланин 2014: 589), такой же, как в болгарских рукописях НБКМ, № 1036 (лл. 240-243) (Елесиевич 2014: 226, 229; Буланин 2014: 588-59029) и Гильф., № 35 (54 об.-57) (Буланин 2014: 589), только без конца. Для атрибуции митрополиту Илариону второго произведения ${ }^{30}$ нет убедительных аргументов.

\section{Список сокращений:}

БАН - Библиотека Российской Академии наук (Санкт-Петербург)

Гильф. - Собрание А. Ф. Гильфердинга (ф. 182) (РНБ)

МДА - Собрание Московской духовной академии (ф. 173.I). Фундаментальное (РГБ)

МC - Матица српска (Нови Сад)

НБКМ - Национална библиотека «Св. св. Кирил и Методий» (София)

НБС - Народна библиотека Србије (Београд)

РГБ - Российская государственная библиотека (Москва)

РНБ - Российская национальная библиотека

Сав. - Собрание монастыря Савина (Черногория)

Соф. - Собрание Библиотеки Новгородского Софийского собора (РНБ)

Тек. пост. - Собрание Текущих поступлений (БАН)

ТСЛ - Собрание Троице-Сергиевой лавры (ф. 304.І). Основное (РГБ)

Хил. - Собрание Хиландарского монастыря

25 За указание на этот список благодарим итальянского исследователя Марко Скарпа.

${ }^{26}$ См. прим. 15.

${ }_{27}^{27}$ Согласно П. П. Панаитеску, рукопись, вероятно, написана в Молдавии (Panaitescu 1959: 393-394, № 294).

${ }^{28}$ Сердечно благодарим болгарскую исследовательницу Марию Йовчеву, приславшего нам работу Боню Ангелова.

${ }^{29}$ Исследователь неверно указал листы в НБКМ, 1036 (Буланин 2014: 589), объединив эту компиляцию со следующей за ней, упомянутой выше.

30 Литуратуру о нем см.: Буланин 2014: 161 («Поучение о отвержении мира»); Горскій 1844: 222. 


\section{Использованная литература}

Ангелов, Боню Ст. Из старата българска, руска и сръбска литература. София: Българска академия на науките, 1958.

[Angelov, Bonû St. Iz starata b"lgarska, ruska i sr"bska literatura. Sofiâ: B"lgarska akademiâ na naukite, 1958]

Белякова, Елена В. «Скитский устав по рукописи РНБ. Погод. 876». Древняя Русь. Вопросы медиевистики 1 (11), 2003: 63-95.

[Belâkova, Elenav V. «Skitskij ustav po rukopisi RNB. Pogod. 876». Drevnââ Rus'. Voprosy medievistiki 1 (11), 2003: 63-95]

Белякова, Елена В., Татьяна В. Пентковская, Марко Скарпа. «Монастырские библиотеки и пути распространения исихастской традиции середины XIV - XV вв. из Парории в Белозерье: современное состояние изучения проблемы». Stephanos 4/42, 2020: 47-65.

[Belâkova, Elena V., Tat'âna V. Pentkovskaâ, Marko Skarpa. «Monastyrskie biblioteki i puti rasprostraneniâ isihastskoj tradicii serediny XIV - XV vv. iz Parorii v Belozer'e: sovremennoe sostoânie izučeniâ problemy». Stephanos 42/4, 2020: 47-65]

Буланин, Дмитрий М. (ред.) Каталог памятников древнерусской письменности XIXIV вв. (Рукописные книги). Санкт-Петербург: Дмитрий Буланин, 2014.

[Bulanin, Dmitrij M. (red.) Katalog pamâtnikov drevnerusskoj pis'mennosti XI-XIV vv. (Rukopisnye knigi). Sankt-Peterburg: Dmitrij Bulanin, 2014]

Буланин, Дмитрий М. «Приложения. Текстологические и библиографические арабески». [В:] Буланин, Дмитрий М. (ред.) Каталог памятников древнерусской письменности XI-XIV вв. (Рукописные книги). Санкт-Петербург: Дмитрий Буланин, 2014, 435-625.

[Bulanin, Dmitrij M. «Priloženiâ. Tekstologičeskie i bibliografičeskie arabeski». [V:] Bulanin, Dmitrij M. (red.) Katalog pamâtnikov drevnerusskoj pis'mennosti XI-XIV vv. (Rukopisnye knigi). Sankt-Peterburg: Dmitrij Bulanin, 2014, 435-625]

Булгаков, Макарий, митрополит Московский и Коломенский. История Русской Церкви. Кн. II. Москва: Издательство Спасо-Преображенского Валаамского монастыря, 1995.

[Bulgakov, Makarij, mitropolit Moskovskij i Kolomenskij. Istoriâ Russkoj Cerkvi. Kn. II. Moskva: Izdatel'stvo Spaso-Preobraženskogo Valaamskogo monastyrâ, 1995]

Веретенников, Макарий архим., Михаил В. Печников, «Никифор I». [B:] Патриарх Московский и всея Руси Кирилл (ред.) Православная энциклопедия. T. XLIX. Москва: Церковно-научный центр «Православная энциклопедия», 2018, 621627.

[Veretennikov, Makarij arhim., Mihail V. Pečnikov, «Nikifor I». [V:] Patriarh Moskovskij i vseâ Rusi Kirill (red.) Pravoslavnaâ ènciklopediâ, T. XLIX, Moskva: Cerkovnonaučnyj centr «Pravoslavnaâ ènciklopediâ», 2018, 621-627]

Вуксан, Душан Д. «Рукописи манастира Пећке патријаршије». Зборник за историју јужне Србије и суседних области 1, 1936: 133-189.

[Vuksan, Dušan D. «Rukopisi manastira Pećke patrijaršije». Zbornik za istoriju južne Srbije i susednih oblasti 1, 1936: 133-189]

[Горскій, Александръ В.] «Памятники духовной литературы временъ Великаго Князя Ярослава І». Прибавленія къ твореніямъ святыхъ отцевъ, въ русскомъ переводњ 2, 1844: 204-299. 
[[Gorskij, Aleksandr" V.] «Pamâtniki duhovnoj literatury vremen" Velikago Knâzâ Âroslava I». Pribavleniâ k" tvoreniâm" svâtyh" otcev", v" russkom" perevode 2, 1844: 204-299]

Гранстрем, Евгения Э. Описание русских и славянских пергаменных рукописей. Рукописи русские, болгарские, молдовлахийские, сербские. Ленинград: Государственная ордена Трудового красного знамени Публичная библиотека имени М. Е. Салтыкова-Щедрина, 1953.

[Granstrem, Evgeniâ È. Opisanie russkih i slavânskih pergamennyh rukopisej. Rukopisi russkie, bolgarskie, moldovlahijskie, serbskie. Leningrad: Gosudarstvennaâ ordena Trudovogo krasnogo znameni Publičnaâ biblioteka imeni M. E. Saltykova-Ŝedrina, 1953]

Гроздановић-Пајић, Мирослава, Радоман Станковић. «Датирање и водени знаци српских ћирилских рукописних књига Пећке патријаршије». Археографски прилози 13, 1991: 7-249.

[Grozdanović-Pajić, Miroslava, Radoman Stanković. «Datiranje i vodeni znaci srpskih ćirilskih rukopisnih knjiga Pećke patrijaršije». Arheografski prilozi 13, 1991: 7-249]

Громов, Михаил Н., Сергей М. Полянский (ред.) Творения митрополита Никифора. Москва: Наука 2006.

[Gromov, Mihail N., Sergej M. Polânskij (red.) Tvoreniâ mitropolita Nikifora. Moskva: Nauka 2006]

Гумилевскій, Филаретъ, архіепископъ Черниговскій. Обзоръ русской духовной литературы. Книга первая. 862-1720. Изданіе третье, сь поправками и дополненіями автора. С-Петербургъ: Изданіе книгопродавца И. Л. Тузова, 1884.

[Gumilevskij, Filaret", arhiepiskop" Černigovskij. Obzor" russkoj duhovnoj literatury. Kniga pervaâ. 862-1720. Izdanie tret'e, s" popravkami i dopolneniâmi avtora. S-Peterburg": Izdanie knigoprodavca I. L. Tuzova, 1884]

Јелесијевић, Снежана. «Извод из „Слова брату столпнику“ у хиландарском зборнику из XVIII века». Филолошки преглед 39, 2012: 177-187.

[Jelesijević, Snežana. «Izvod iz „Slova bratu stolpniku“ u hilandarskom zborniku iz XVIII veka». Filološki pregled 39, 2012: 177-187]

Јелесијевић, Снежана В. Изворна књижевна дела Кијевске Русије у српскословенској рукописној традицији. І. Докторска дисертација. Београд, 2012.

[Jelesijević, Snežana V. Izvorna književna dela Kijevske Rusije u srpskoslovenskoj rukopisnoj tradiciji. I. Doktorska disertacija, Beograd, 2012]

Јелесијевић, Снежана В. Изворна књижевна дела Кијевске Русије у српскословенској рукописној традицији. II. Докторска дисертација. Београд, 2012.

[Jelesijević, Snežana V. Izvorna književna dela Kijevske Rusije u srpskoslovenskoj rukopisnoj tradiciji. II. Doktorska disertacija. Beograd, 2012]

Елесиевич, Снежана. «Хиландарский список «Слова митрополита Киевского Илариона к брату столпнику»». [В:] Ж. Л. Левшина (ред.) Афон и славянский мир. Сборник 1. Материалы международной научной конференции посвященной 1000-летию присутствия русских на Святой Горе. Белград, 16-18 мая 2013 г. Святая Гора Афон: Издание Русского Свято-Пантелеимонова монастыря на Афоне, 2014: 223-234.

[Elesievič, Snežana. «Hilandarskij spisok «Slova mitropolita Kievskogo Ilariona k bratu stolpniku»»». [V:] Ž. L. Levšina (red.) Afon i slavânskij mir. Sbornik 1. Materialy meždunarodnoj naučnoj konferencii posvâŝennoj 1000-teliû prisutstviâ russkih na Svâtoj Gore. Belgrad, 16-18 maâ 2013 g. Svâtaâ Gora Afon: Izdanie Russkogo SvâtoPanteleimonova monastyrâ na Afone, 2014: 223-234] 
Јелесијевић, Снежана. «„Слово на Вазнесење Господње” Светог Кирила Туровског у српској рукописној традицији» (в печати).

[Jelesijević, Snežana. «,Slovo na Vaznesenje Gospodnje” Svetog Kirila Turovskog u srpskoj rukopisnoj tradiciji» (v pečati)]

Живов, Виктор М. История языка русской письменности. Т. І. Москва: Университет Дмитрия Пожарского, 2017.

[Živov, Viktor M. Istoriâ âzyka russkoj pis'mennosti. T. I. Moskva: Universitet Dmitriâ Požarskogo, 2017]

Зализняк, Андрей А. Древненовгородский диалект. 2-е издание, переработанное с учетом материала находок 1995-2003 гг. Москва: Языки славянской культуры, 2004.

[Zaliznâk, Andrej A. Drevnenovgorodskij dialekt. 2-e izdanie, pererabotannoe s učetom materiala nahodok 1995-2003 gg. Moskva: Âzyki slavânskoj kul'tury, 2004]

Иванова Климентина. Bibliotheca Hagiographica Balcano-Slavica. София: Академично издателство „Марин Дринов”, 2008.

[Ivanova Klimentina. Bibliotheca Hagiographica Balcano-Slavica. Sofiâ: Akademično izdatelstvo „Marin Drinov”, 2008]

[Иларий, иером. и Арсений, иером.]. Описаніе славянскихъ рукописей библіотеки Свято-Троицкой Сергіевой лавры. Часть I. Москва: Изданіе Императорскаго Общества Исторіи и Древностей Россійскихъ при Московскомъ Университетъ, 1878 (Чтенія въ Императорскомъ Обществъ Исторіи и Древностей Россійскихъ при Московскомъ Университетъ 2, 1878).

[[Ilarij, ierom. i Arsenij, ierom.]. Opisanie slavânskih" rukopisej biblioteki Svâto-Troickoj Sergievoj lavry. Čast' I. Moskva: Izdanie Imperatorskago Obŝestva Istorii i Drevnostej Rossijskih" pri Moskovskom" Universitete, 1878 (Čteniâ v" Imperatorskom" Obŝestve Istorii i Drevnostej Rossijskih" pri Moskovskom" Universitete 2, 1878)]

Леонидъ, архимандритъ. Свъдъніе о славянскихъ рукописяхъ, поступившихъ изъ книгохранилища Св. Троицкой Сергіевой Лавры въ библіотеку Троицкой Духовной Семинаріи въ 1747 году, (нынъ находящихся въ библіотекъ Московской Духовной Академіи.). Вып. 2. Москва: Изданіе Императорскаго Общества Исторіи и Древностей Россійскихъ при Московскомъ Университетъ, 1887.

[Leonid", arhimandrit". Svedenie o slavânskih" rukopisâh", postupivših" iz" knigohraniliŝa Sv. Troickoj Sergievoj Lavry v" biblioteku Troickoj Duhovnoj Seminarii v" 1747 godu, (nyne nahodâsihhsâ v" biblioteke Moskovskoj Duhovnoj Akademii.). Vyp. 2. Moskva: Izdanie Imperatorskago Obŝestva Istorii i Drevnostej Rossijskih" pri Moskovskom" Universitete, 1887]

Лосева, Ольга В. Жития русских святых в составе древнерусских прологов XII первой трети XV веков. Москва: Рукописные памятники Древней Руси, 2009.

[Loseva, Ol'ga V. Žitiâ russkih svâtyh v sostave drevnerusskih prologov XII - pervoj treti XV vekov. Moskva: Rukopisnye pamâtniki Drevnej Rusi, 2009]

Мирчев, Кирил. Историческа граматика на българския език. Второ издание. София: Държавно издателство „Наука и изкуство“, 1963.

[Mirčev, Kiril. Istoričeska gramatika na b"lgarskiâ ezik. Vtoro izdanie. Sofiâ: D"ržavno izdatelstvo „Nauka i izkustvo“e, 1963]

Младеновић, Александар. «Елементи историје српскохрватског језика». [B:] Opšta enciklopedija Larousse u 3 toma. T. 1. Beograd: Vuk Karadžić - Interexport, 1971, 419-426.

[Mladenović, Aleksandar. «Elementi istorije srpskohrvatskog jezika». [V:] Opšta enciklopedija 
Larousse u tri toma, T. 1. Beograd: Vuk Karadžić - Interexport, 1971, 419-426]

Молдован, Александр М. «Слово о законе и благодати» Илариона. Киев: Наукова дума, 1984.

[Moldovan, Aleksandr M. «Slovo o zakone i blagodati» Ilariona. Kiev: Naukova duma, 1984]

Мошин, Владимир. «Рукописи Пећке патријаршије». Старине Косова и Метохије 4-5, 1968-1971: 5-137.

[Mošin, Vladimir. «Rukopisi Pećke patrijaršije». Starine Kosova i Metohije 4-5, 19681971: 5-137]

Никольскій, Николай. Матеріалы для повременнаго списка русскихъ писателей и ихъ сочиненій. (X-XI вв.). Корректурное изданіе. С.-Петербургъ: Отдъленіе русскаго языка и словесности Императорской Академіи Наукъ, 1906.

[Nikol'skij, Nikolaj. Materialy dlâ povremennago spiska russkih" pisatelej i ih" sočinenij. (X-XI vv.). Korrekturnoe izdanie. S.-Peterburg": Otdelenie russkago âzyka i slovesnosti Imperatorskoj Akademii Nauk", 1906]

Опись фонда № 704. Ундольский Вукол Михайлович (Документы 1815-1870 гг.). Москва: Государственная библиотека СССР имени В. И. Ленина. Отдел рукописей, 1980 (машинопись).

[Opis' fonda № 704. Undol'skij Vukol Mihajlovič (Dokumenty 1815-1870 gg.). Moskva: Gosudarstvennaâ biblioteka SSSR imeni V. I. Lenina. Otdel rukopisej, 1980 (mašinopis')]

Петровскій, Мемнонъ. Поученіе, приписываемое Иларіону митрополиту Кіевскому. Казань: Въ Университетской типографіи, 1865.

[Petrovskij, Memnon". Poučenie, pripisyvaemoe Ilarionu mitropolitu Kievskomu. Kazan': V" Universitetskoj tipografii, 1865]

П[етровск]ій, Мемнонъ. «Иларіонъ, митрополитъ Кіевскій и Доментіанъ, іеромонах Хиландарскій». Извђстія Отдъленія русскаго языка и словесности Императорской Академіи наукъ 13/4, 1909: 81-133.

[P[etrovsk]ij, Memnon". «Ilarion", mitropolit" Kievskij i Domentian", ieromonah Hilandarskij». Izvbstiâ Otdظleniâ russkago âzyka i slovesnosti Imperatorskoj Akademii nauk" 13/4, 1909: 81-133]

Творогов, Олег В., Вячеслав М. Загребин (ред.) Рукописные книги М. П. Погодина. Каталог. Вып. 1. Ленинград: Министерство культуры РСФСР, Государственная ордена Трудового красного знамени Публичная библиотека им. М. Е. СалтыковаЩедрина, 1988.

[Tvorogov, Oleg V., Vâčeslav M. Zagrebin (red.) Rukopisnye knigi M. P. Pogodina. Katalog. Vyp. 1. Leningrad: Ministerstvo kul'tury RSFSR, Gosudarstvennaâ ordena Trudovogo krasnogo znameni Publičnaâ biblioteka im. M. E. Saltykova-Ŝedrina, 1988]

Турилов, Анатолий А., Э. П. Р., Э. П. И. «Иларион». [В:] Патриарх Московский и всея Руси Кирилл (ред.) Православная энциклопедия, Т. XXII, Москва: Церковнонаучный центр «Православная энциклопедия», 2009, 122-126.

[Turilov, Anatolij A., È. P. R. «Ilarion». [V:] Patriarh Moskovskij i vseâ Rusi Kirill (red.) Pravoslavnaâ ènciklopediâ, T. XXII, Moskva: Cerkovno-naučnyj centr «Pravoslavnaâ ènciklopediâ», 2009, 122-126]

Турилов, Анатолий А. «Из истории русско-южнославянских книжных связей XIIXIII вв.: новое и забытое». Russica Romana 17, 2011, 9-32.

[Turilov, Anatolij A. «Iz istorii russko-ûžnoslavânskih knižnyh svâzej XII-XIII vv.: novoe i zabytoe». Russica Romana 17, 2011: 9-32]

Турилов, Анатолий А. «Памятники древнерусской литературы и письменности у 
южных славян в XII-XIV вв. (Проблемы и перспективы изучения)». [B:] А. А. Турилов, Исследования по славянскому и сербскому средневековью, Београд 2014, 139-201.

[Turilov, Anatolij A. «Pamâtniki drevnerusskoj literatury i pis'mennosti u ûžnyh slavân v XII-XIV vv. (Problemy i perspektivy izučeniâ)». [V:] A. A. Turilov, Issledovaniâ po slavânskomu i serbskomu srednevekov'û, Beograd 2014, 139-201]

Штављанин-Ђорђевић, Љубица, Мирослава Гроздановић-Пајић, Луција Цернић. Опис ћирилских рукописа Народне библиотеке Србије. Књ. І. Београд: Народна библиотека Србије, 1986.

[Štavljanin-Đorđević Ljubica, Grozdanović-Pajić Miroslava, Cernić Lucija. Opis ćirilskih rukopisa Narodne biblioteke Srbije. Knj. I. Beograd: Narodna biblioteka Srbije, 1986]

Panaitescu, Petre P. Manuscrisele slave din Biblioteca Academiei R P R. Vol. I. Editura Acaemiei Republicii Populare Romîne, 1959.

Vetochnikov, Konstantinos. «Le titre officiel des métropolites russes au Moyen Âge». [B:] M.-H. Blanchet, M.-H. Congourdeau, D. I. Mureșan (réds.) De Patriarchat œcuménique de Constantinople et Byzance hors frontières (1204-1586). Actes de la table ronde organisée dans la cadre du $22^{\mathrm{e}}$ Congrès International des Études Byzantines, Sofia, 22-27 août 2011. Paris: Le Centre d'études byzantines, néo-helléniques et sudest européennes, École des Hautes Études en Sciences Sociales, 2014, 273-307. 


\section{[Приложение 1]}

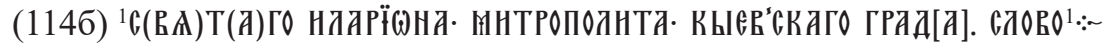

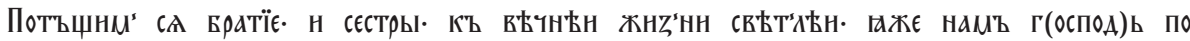

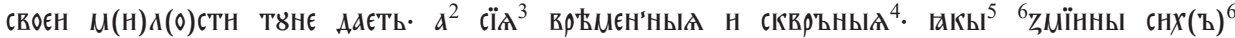

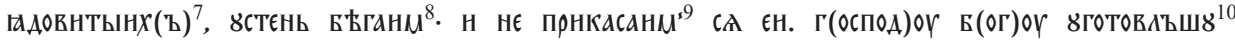

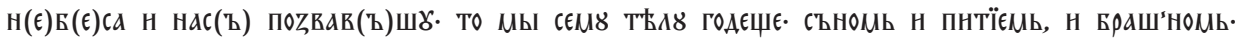

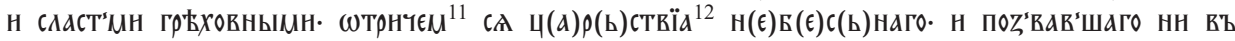

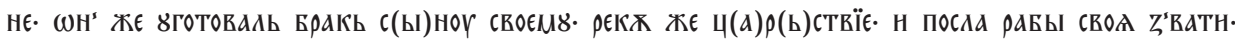

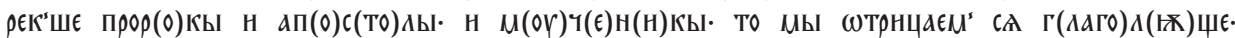

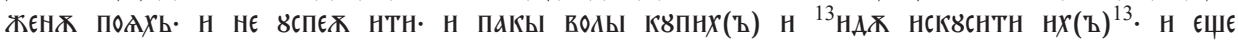

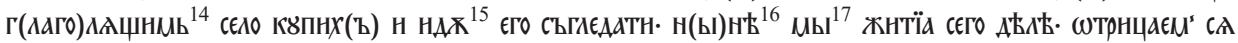

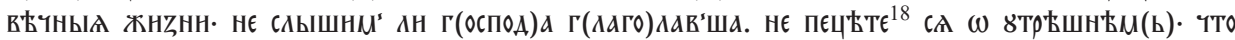
मасТЕ ТТО ${ }^{19}$ ПНЕТЕ. НАН БЪ ТТО

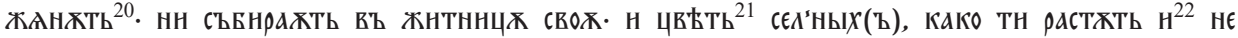

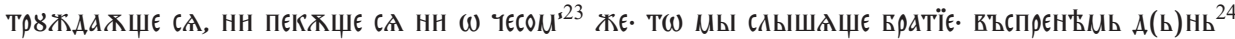

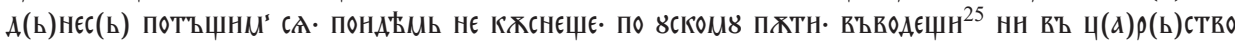

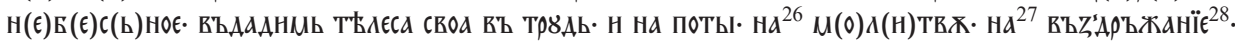

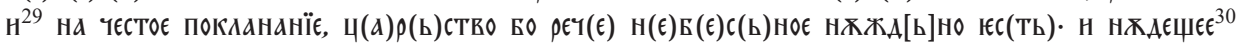

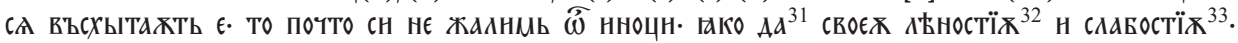

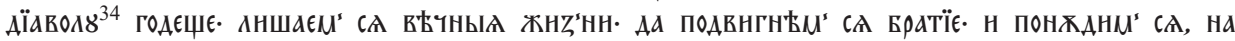

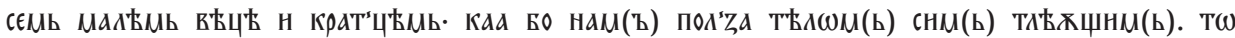
ащє ${ }^{35}$ Бых

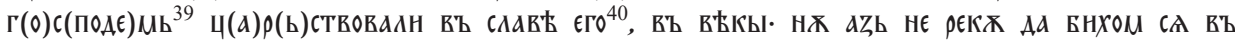

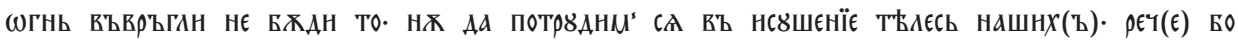

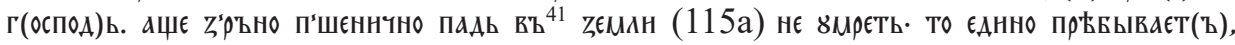

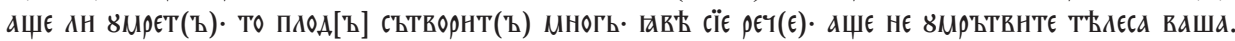

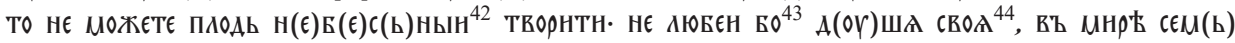

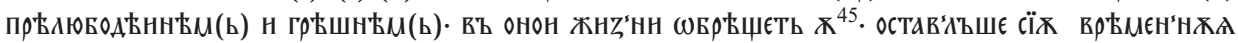

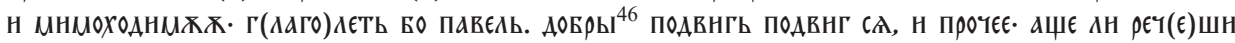

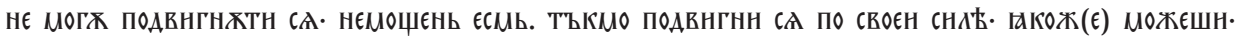

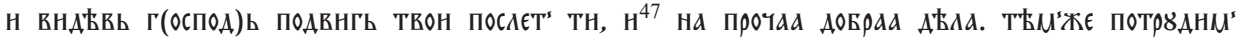

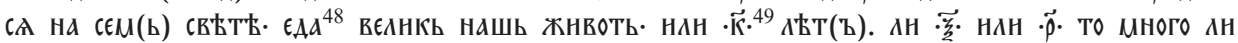

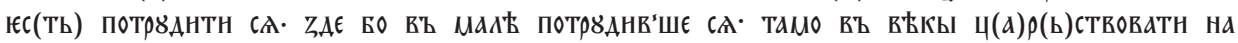

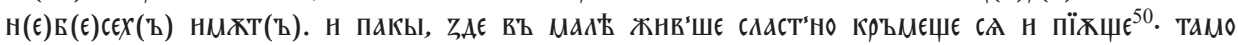

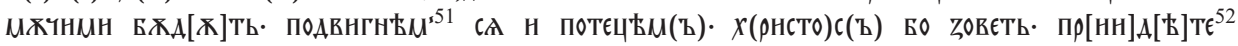
въсн Тр8жАахще ${ }^{53}$ СА, н

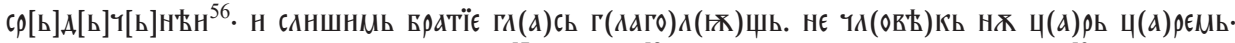

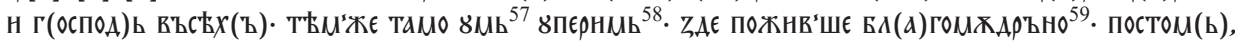

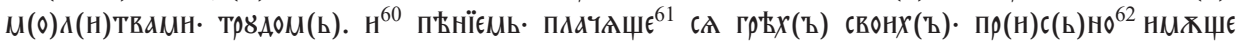

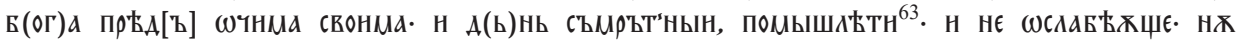

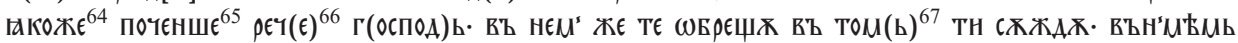

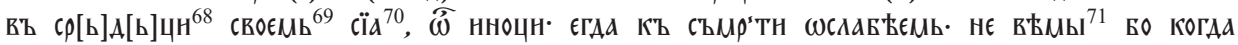

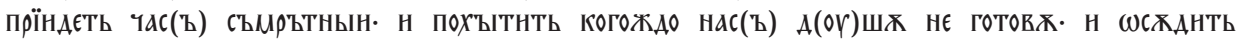
Х въ

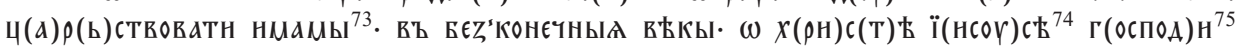




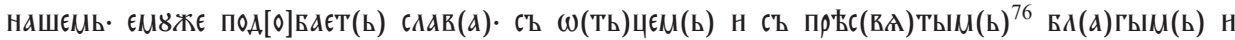

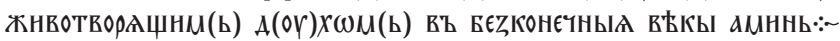

'Т: СЛОВО С(ВА)Т(А)ГО ПАРНОНА ННТРОПОЛНТА КНЮЕВЬКОГО; В: СЛОВО СВЯТАГО ИЛАРІОНА, МИТРОПОЛИТА («Митрополиты», см.: Горскій 1844: 219) КІЕВСКАГО; П: Святаго Иларіона, Митрополита Кіевскаго, слово; ${ }^{2} \mathrm{~T}$, В: н ${ }^{3} \mathrm{~T}$, В: сєА ${ }^{4} \mathrm{~T}$, В: сквєрненыА ${ }^{5} \mathrm{~T}$, В: акн ${ }^{6} \mathrm{~T}$, В: змннныхъ ${ }^{7} \mathrm{~T}, \mathrm{~B}$ : гадовнттыхъ ${ }^{8} \mathrm{~T}$, В: вьгаємь ${ }^{9} \mathrm{~T}$, В: прнкасаємъ ${ }^{10} \mathrm{~T}$, В: оүготовнвъшю ${ }^{11} \mathrm{~T}$, В: $\omega$ Трет(є) М(ь) ${ }^{12} \mathrm{~T}$, В: ц(а)р(ь)ства ${ }^{13} \mathrm{~T}$, В: нскүснтн нхъ ндү (в Т ндү надписано) ${ }^{14} \mathrm{~T}, \mathrm{~B}:$ г (лаго)лющниъъ ${ }^{15} \mathrm{~T}$, В: ндохъ ${ }^{16} \mathrm{~T}$ : нына ${ }^{17} \mathrm{~B}$, П: нет

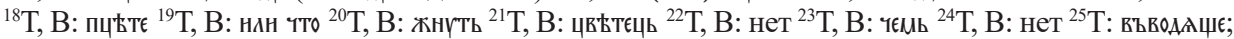
В: въводящему ${ }^{26} \mathrm{~T}, \mathrm{~B}:$ н ${ }^{27} \mathrm{~T}$, В: н на ${ }^{28} \mathrm{~T}$, В: въZдєржаннга ${ }^{29} \mathrm{~T}, \mathrm{~B}:$ нет ${ }^{30} \mathrm{~T}$, В: ногдАшєн ${ }^{31} \mathrm{~T}, \mathrm{~B}:$ нет ${ }^{32} \mathrm{~T}$, В:

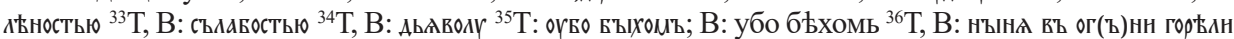

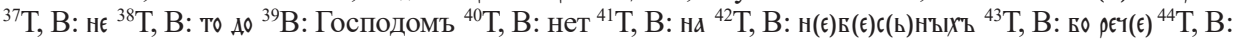

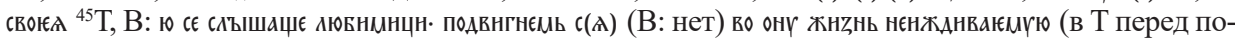
следним словом более темными чернилами написан знак вставки; на верхнем поле такими же чернилами и почерком, отличающимся от почерка писца поучения, после такого же знака напи-

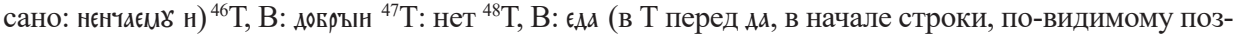
же, добавлено $\epsilon$; такое $\epsilon$ дважды написано в части текста, дописанной, на наш взгляд, иным почерком вдоль правого поля л. 211) ${ }^{49} \mathrm{~B}$ : н (так мы читаем это число в издании прот. А. В. Горского)

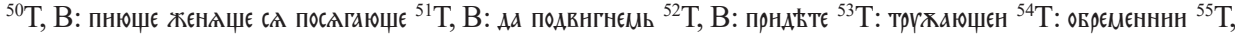

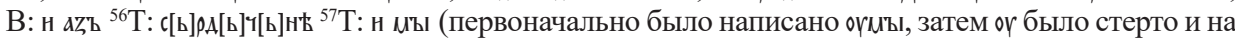
месте $r$ более темными чернилами и, по нашему мнению, иным почерком было написано н; после вмешательств получилось н мы, но так как оставшиеся следы стертого о из оү похожи на с, то можно прочитать и так: сн мы); В: си мы; П (?) = Печ. ${ }^{58} \mathrm{~T}$, В: впєрниь с(А); П (?): вперимь (П = Печ.) ${ }^{59} \mathrm{~T}$, В: в (о)гомүАєєно (в Т первоначально было в плачюще ${ }^{62} \mathrm{~T}$, В: н прнсно ${ }^{63}$ после в написано $\mathrm{X}$, затем оно слегка затерто; на правом поле, напротив

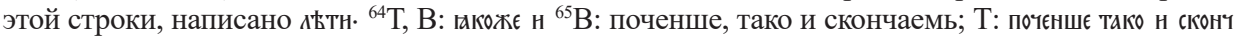
(над ч буква є (?) под тилом) (по-видимому, дописано иным почерком; не тем ли, которым написано н на месте стертого ү (57)?); П = Печ. ${ }^{66} \mathrm{~T}, \mathrm{~B}:$ Рєч(є) во ${ }^{67} \mathrm{~T}$, В: томъ жє ${ }^{68} \mathrm{~T}, \mathrm{~B}:$ с (ь)рА(ь)ца ${ }^{69} \mathrm{~T}, \mathrm{~B}:$ свога

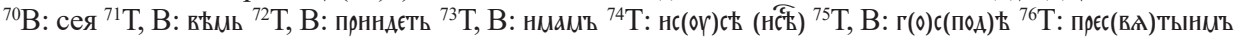

\section{Снежана Јелесијевић}

\section{БУГАРСКИ ПРЕПИС „ПОУКЕ О ДУШЕВНОЈ КОРИСТИ” МИТРОПОЛИТА КИЈЕВСКОГ ИЛАРИОНА}

\section{Резиме}

Протојереју Александру В. Горском су била позната два руска преписа ове поуке - Волоколамски и Погодинов (крај XIV - почетак XV века) - где се у заглављу као писац помиње „Свети Иларион, митрополит кијевски”. Споменути проучавалац је објавио Волоколамски препис, уневши у њега три или четири чтенија из преписа РГБ, МДА, бр. 175 (XVI и XVII век) и, по свој прилици, најмање две речи из Погодиновог. Волоколамски и Погодинов рукопис данас нису познати. Николај К. Никољски је указао на препис поуке у Зборнику РБГ, TCЛ 13, датираном крајем XIV - почетком XV века, где се она у заглављу приписује такође „Светом Лариону, митрополиту кијевском”. Она му се, премда не непосредно, приписује и у двама српским преписима из треће четвртине XIV века - БАН, Тек. пост. 13 и НБС 26. Бугарски препис се налази у Монашком зборнику Збирке Пећке патријаршије, датираном првом деценијом XV века. Уникатан је по именовању аутора - „Свети Иларион, митрополит Кијевског града“. У прилогу рада је издање тог преписа, са разночтенијима из преписа РГБ, ТСЛ, бр. 13 и издања протојереја Александра В. Горског.

Кључне речи: митрополит Иларион, „Поука о душевној користи”, Пећка патријаршија. 


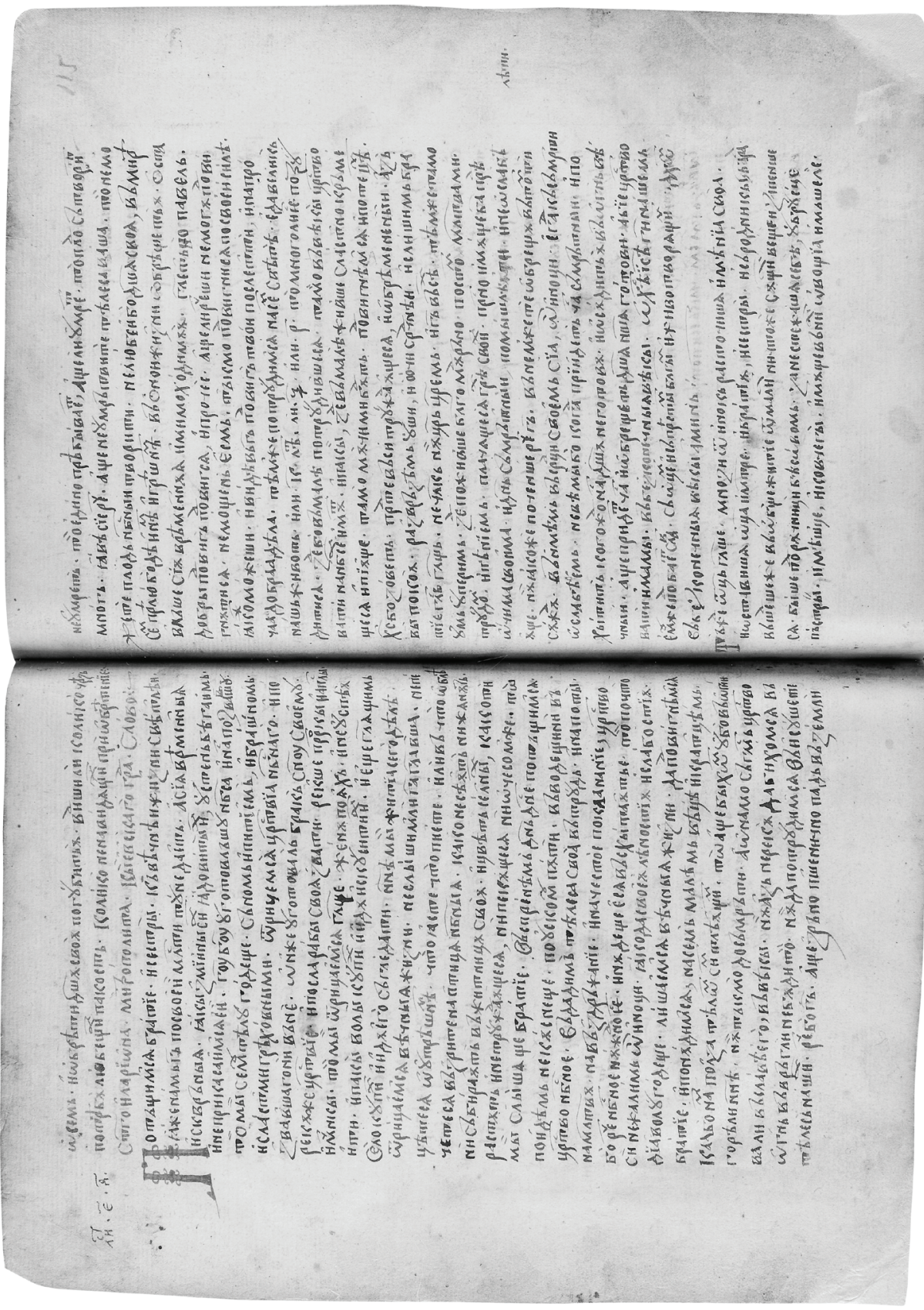

Приложение 2. Собрание рукописей Печской патриархии, № 93, лл. 114 об. -115 